\title{
Molecular Marker Mapping of Leaf Rust Resistance Gene Lr46 and Its Association with Stripe Rust Resistance Gene Yr29 in Wheat
}

\author{
M. William, R. P. Singh, J. Huerta-Espino, S. Ortiz Islas, and D. Hoisington
}

First, second, fourth, and fifth authors: International Maize and Wheat Improvement Center (CIMMYT), Apartado Postal 6-641, 06600, Mexico, D.F.; third author: Campo Experimental Valle de Mexico-INIFAP, Apdo. Postal 10, 56230, Chapingo, Edo. de Mexico; and first and fifth authors: Cooperative Research Center for Molecular Plant Breeding, Australia.

Accepted for publication 14 August 2002.

\begin{abstract}
William, M., Singh, R. P., Huerta-Espino, J., Ortiz Islas, S., and Hoisington, D. 2003. Molecular marker mapping of leaf rust resistance gene Lr46 and its association with stripe rust resistance gene $\operatorname{Yr} 29$ in wheat. Phytopathology 93:153-159.

Leaf and stripe rusts, caused by Puccinia triticina and P. striiformis, respectively, are globally important fungal diseases of wheat that cause significant annual yield losses. A gene that confers slow rusting resistance to leaf rust, designated as $L r 46$, has recently been located on wheat chromosome $1 \mathrm{~B}$. The objectives of our study were to establish the precise genomic location of gene Lr46 using molecular approaches and to determine if there was an association of this locus with adult plant

developed and classified for leaf rust and stripe rust severity for three seasons. Using patterns of segregation for the two diseases, we estimated that at least two genes with additive effects conferred resistance to leaf rust and three to four genes conferred resistance to stripe rust. Bulked segregant analysis and linkage mapping using amplified fragment length polymorphisms with the 'Avocet' $\times$ 'Pavon 76 ' population, $F_{3}$ progeny lines of a single chromosome recombinant line population from the cross 'Lalbahadur' $\times$ 'Lalbahadur (Pavon 1B)', and the International Triticeae Mapping Initiative population established the genomic location of $\mathrm{Lr} 46$ at the distal end of the long arm of wheat chromosome 1B. A gene that is closely linked to Lr46 and confers moderate levels of adult plant resistance to stripe rust is identified and designated as $\operatorname{Yr} 29$.
\end{abstract} resistance to stripe rust. A population of $146 \mathrm{~F}_{5}$ and $\mathrm{F}_{6}$ lines produced from the cross of susceptible 'Avocet S' with resistant 'Pavon 76' was

Stripe (yellow) rust, caused by Puccinia striiformis West., and leaf (brown) rust, caused by $P$. triticina, are important diseases of wheat globally. A number of genes conferring resistance to these diseases are known to be present in hexaploid wheat (Triticum aestivum L.) (22). However, a majority of these resistance genes are not effective against current races of $P$. striiformis or $P$. triticina (23). Past experience has shown that resistance conditioned by major genes is short lived when used commercially because this form of resistance can be easily overcome by mutation and selection of virulence in rust pathogens. In recent years, geneticists and plant breeders have emphasized the importance of developing and deploying cultivars that carry durable or slow rusting resistance based on quantitatively inherited multiple genes $(3,14,16,31,34)$. The moderate resistance to leaf and stripe rust conferred by the linked (or pleiotropic) genes $\mathrm{Lr} 34 / \mathrm{Yr} 18$ has been effective for more than 50 years and thus is regarded as an example of durable resistance $(7,8,17,21,37,43)$.

Breeding efforts at the International Wheat and Maize Improvement Center (CIMMYT) have resulted in the release of numerous wheat cultivars that contain the linked genes $\operatorname{Lr} 34 / \mathrm{Yr} 18(43,44)$. Singh and Rajaram $(48,49)$ indicated that CIMMYT-derived cultivars having higher levels of slow rusting/adult-plant resistance to leaf or stripe rust often carried two to three minor genes with additive effects. More recently, Singh et al. (46) designated the gene symbol Lr46 to a gene that conferred slow rusting to leaf rust and located it to chromosome $1 \mathrm{~B}$ of wheat cv. Pavon 76 which has remained effective since its release in 1976. Although 'Pavon 76' does not carry the gene $\mathrm{Yr} 18$, its adult-plant resistance

Corresponding author: M. William; E-mail address: m.william@cgiar.org

Publication no. P-2002-1125-02R

(C) 2003 The American Phytopathological Society
Additional keywords: Triticum aestivum. to stripe rust has remained effective in areas of Mexico, Ethiopia, Australia, and other countries where it is grown under high stripe rust pressure.

Molecular markers are powerful tools for identifying quantitative traits and dissecting these complex traits into Mendelian factors in the form of quantitative trait loci (QTL) as well as for establishing the genomic locations of such genetic loci. Bulked segregant analysis (BSA), which involves pooling of entries at the two extremes for a segregating trait (26), has been effectively used for identifying molecular markers associated with disease resistance genes in a number of species $(36,53)$. In wheat, due to the large size and the hexaploid nature of the genome, few markers have been identified for traits of importance although there are some recent reports of success $(10,13,15)$. However, when genes are introgressed from wild relatives, the potential for successful marker identification of the introgressed genes is greater due to the higher levels of polymorphisms observed. Examples of such gene tagging include $\mathrm{Yr} 17$, Lr37, and $\mathrm{Sr} 38$ present in a segment of chromosome introgressed from Aegilops ventricosa (41), Yr15 from T. dicoccoides (4), Lr9 (40), Lr19 (33), Lr24 (39), and Lr39 (35). BSA and linkage mapping in wheat has also enabled identification of molecular markers associated with genes that condition resistance to leaf rust (52) and stripe rust (4). BSA with T. tauschii segregating for cereal cyst nematode $(\mathrm{CCN})$ resistance has enabled identification of molecular markers for resistance to CCN (9). Linkage mapping studies have also identified quantitative loci conditioning resistance to leaf rust in 'Opata' $\times$ 'Synthetic' population (28) and 'Forno' $\times$ 'Oberkulmar' (25). Genetic factors conditioning resistance to scab have also been characterized with molecular markers (1).

The objectives of our study were to (i) determine the precise location of Lr46 in chromosome 1B using molecular markers and (ii) study the genetic association of Lr46 with adult plant resistance to stripe rust. 


\section{MATERIALS AND METHODS}

Development and evaluation of 'Avocet $S^{\prime} \times$ 'Pavon $\mathbf{7 6}^{\prime}$ ' $\mathbf{F}_{\mathbf{5}}$ and $\mathbf{F}_{\mathbf{6}}$ lines. The first population used in the study was derived from the cross of leaf rust and stripe rust susceptible 'Avocet $S$ ' with 'Pavon 76' that carries Lr46. A total of 146 individual $\mathrm{F}_{2}$ plant-derived $\mathrm{F}_{5}$ and $\mathrm{F}_{6}$ lines were obtained by harvesting a random spike from each $\mathrm{F}_{3}$ line and a random plant from each $\mathrm{F}_{4}$ and $\mathrm{F}_{5}$ line. The $\mathrm{F}_{5}$ lines were evaluated in the field for leaf rust during the 1996 to 1997 season at the CIMMYT research station in Ciudad Obregon (Sonora State) in northwestern Mexico and for stripe rust during the 1996 season at the highland research station at Toluca (Mexico State) near Mexico City. The $\mathrm{F}_{6}$ lines were evaluated for leaf rust for two seasons: during 1997 to 1998 at Ciudad Obregon and during the 1999 crop season at CIMMYT base station at El Batan (Mexico State). The $\mathrm{F}_{6}$ lines were evaluated during the 1997 and 1999 crop seasons at Toluca for stripe rust. All field evaluations were conducted in unreplicated trials. Approximately 60 seeds of each line were sown in $75 \mathrm{~cm}$ wide paired-row plots, $1 \mathrm{~m}$ in length, with $20-\mathrm{cm}$ row spacing and a 50 -cm pathway between plots. The leaf rust and stripe rust epi-
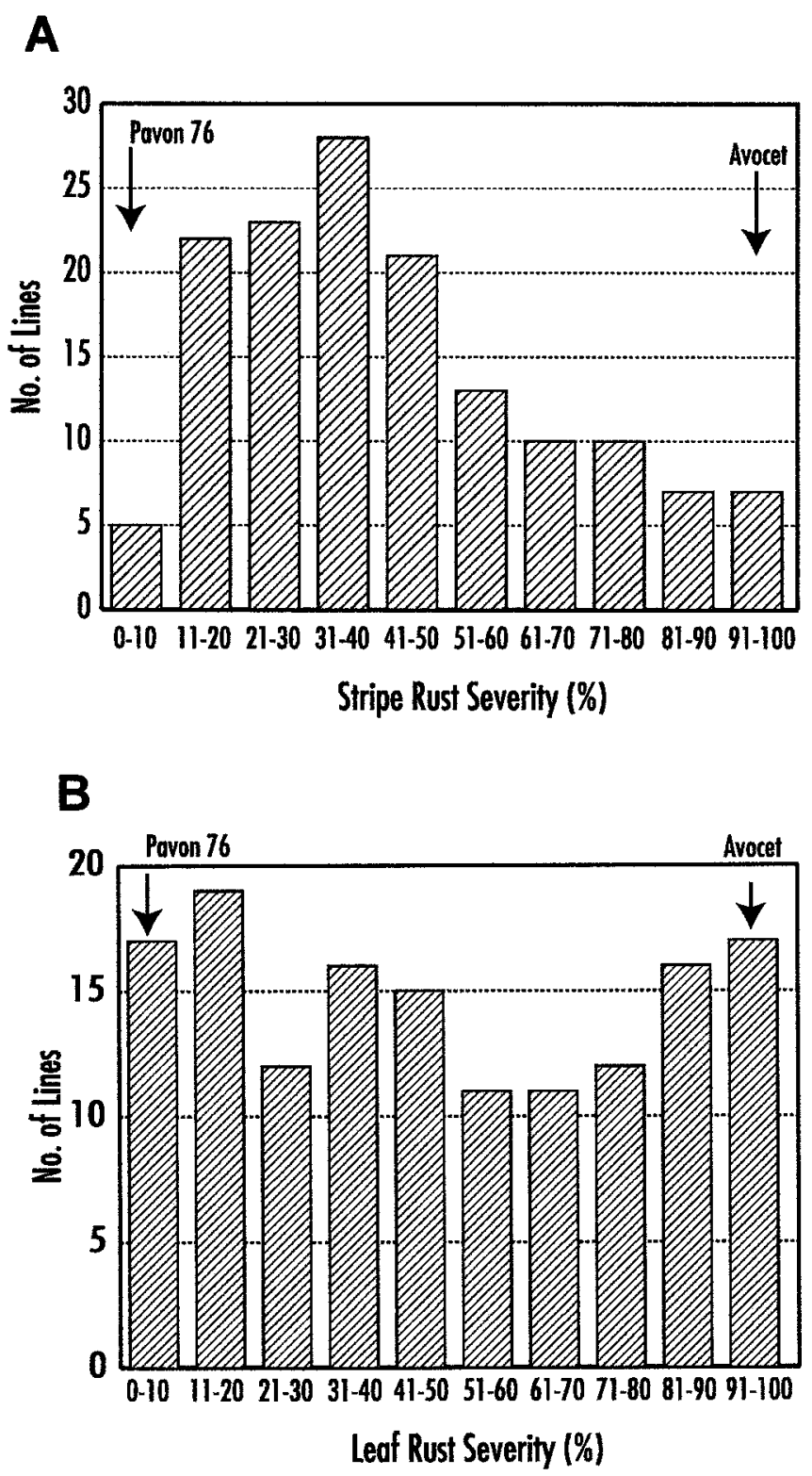

Fig. 1. Histograms of mean adult-plant $\mathbf{A}$, stripe rust severities and $\mathbf{B}$, leaf rust severities of 146 recombinant inbred lines from the cross 'Avocet' $\times$ 'Pavon 76'. Percent averages of 3 years of data were used. demics were initiated approximately 6 weeks after planting at Ciudad Obregon and 4 weeks after planting at Toluca and El Batan. Spreader rows of highly susceptible cv. Morocco, planted in hills on one side of the plots in the pathway, were sprayed with a suspension of urediniospores in lightweight mineral oil Soltrol 170 (Phillips 66 Co., Bartlesville, OK). All three field sites have a favorable environment for the respective disease development. The Mexican P. triticina race MCJ/SP, nomenclature based on Singh (42), used in all studies has the avirulence/virulence formula $\operatorname{Lr} 2 a, 2 b, 2 c, 3 k a, 9,16,19,21,24,25,28,29,30,32,33 / 1,(3)$, $3 b g, 10,11,12,13,14 a, 14 b, 15,17,18,20,22 b, 23,26,27+31$. The $P$. striiformis culture Mex96.11 used in all studies has the avirulence/virulence formula $\mathrm{Yr} 1,4,5,8,10,15,17,24, \mathrm{Sp} / 2,3,6,7,9,27, \mathrm{~A}$. Fresh inoculum obtained by multiplying urediniospores on susceptible cv. Morocco in the greenhouse was used for all inoculations. Both 'Pavon 76' and 'Avocet S' display susceptible seedling reactions to these races. In all cases of field screening, parents were included with the population.

The visual estimates of adult-plant rust severities were based on the modified Cobb scale (32). The host response to infection (infection types) to stripe rust followed a 0 -to-9 scale as described by McNeal et al. (24), whereas leaf rust infection types were characterized as resistant (R), moderately resistant (MR), moderately susceptible (MS), and susceptible (S) based on the descriptions given in Roelfs et al. (38). The first rust severities and reactions were recorded on flag leaves at about the milk stage of grain development for leaf rust and at flowering for stripe rust, when the susceptible parent displayed severity between 80 and $100 \%$. The severity range (the most resistant and susceptible plants) and average rust severity (estimated visually) were recorded for each $F_{5}$ and $F_{6}$ line. The adult-plant stripe rust infection types of the $\mathrm{F}_{6}$ lines were recorded during 1999 only. The lines were evaluated a second time approximately 12 to 15 days after the first evaluation, when rust had killed leaves of the susceptible parent. Previous CIMMYT studies $(45,46)$ have shown that the timing of the first rating is critical to identify plants or lines that are similar in susceptibility level to the susceptible parent, whereas the second rating is critical to identify plants or lines similar in resistance levels to the resistant parent. On the basis of the two data sets obtained during each of the 2 years of tests, the $F_{6}$ lines were grouped into three categories: homozygous parental-type resistant (HPTR); homozygous parental-type susceptible (HPTS); and other. The lines were grouped into HPTR category when their mean rust severity was less, equal, or up to $5 \%$ higher than that of 'Pavon 76'. Similarly, HPTS lines had mean rust severity either the same or higher than that of 'Avocet S'. Chi-square analyses were carried out to compare the distribution of $\mathrm{F}_{5}$ and $\mathrm{F}_{6}$ phenotypic frequencies with those expected for segregation of two, three, and four additive genes.

Development and evaluation of single chromosome recombinant lines for gene $\mathbf{L} \mathbf{r 6 6}$. Singh et al. (46) substituted chromosome 1B of 'Pavon 76' into a leaf rust susceptible wheat cv. Lalbahadur and developed the disomic substitution line Lalbahadur (Pavon 1B). This substitution line carrying Lr46 was crossed with the susceptible parent 'Lalbahadur'. Five $F_{1}$ plants were individually harvested and $F_{2}$ plants were grown with 10 to $15 \mathrm{~cm}$ spacing between them. A total of $184 \mathrm{~F}_{3}$ lines ( 34 to 38 per $\mathrm{F}_{2}$ family) were obtained by harvesting individual $F_{2}$ plants. The $F_{3}$ lines were evaluated for two seasons (1998 to 1999 and 1999 to 2000) at Ciudad Obregon with $P$. triticina race MCJ/SP. All plantings and other details were similar to those described for genetic analysis. The lines were classified into three categories: homozygous resistant, segregating, and homozygous susceptible. Chi-square analyses were carried out to compare the distribution of $\mathrm{F}_{3}$ phenotypic frequencies with the 1:2:1 ratio expected for segregation at a single locus.

The ITMI population. The International Triticeae Mapping Initiative (ITMI) Population developed at Cornell University (29) 
was utilized in the genomic location and mapping of one of the two amplified fragment length polymorphism (AFLP) markers that were associated with $L r 46$. The ITMI linkage map contains more than 800 markers and is publicly available $(20,29,30,50)$.

BSA and linkage mapping. The 'Avocet $S$ ' $\times$ 'Pavon 76' recombinant inbred line population and selected $\mathrm{F}_{3}$ lines (40 lines homozygous for Lr46 and another 40 homozygous lines lacking Lr46) from the cross 'Lalbahadur' $\times$ 'Lalbahadur (Pavon 1B)' were grown in the greenhouse for 5 weeks, and leaf tissue was harvested for DNA extraction. DNA was extracted with CTAB (mixed alkyltrimethyl-ammonium bromide)-based protocol as described in Hoisington et al. (12). Three years of field data were used in the 'Avocet' $\times$ 'Pavon 76' population to identify those entries that were HPTR to both leaf rust and stripe rust. DNA of the seven entries that were HPTR to both diseases was mixed in equal quantities to make up the resistant bulk. Similarly, DNA of the 11 entries that were HPTS to both rusts was mixed to make the susceptible bulk. The two parents and two bulks were screened with 48 AFLP primer combinations to identify polymorphisms that were consistent between the parents and the bulks. Polymorphic AFLPs, which distinguished the bulks, were screened across the entire population. Linkage analysis was done using MAPMAKER 2.0 (19). Simple linear regression was used to calculate the coefficient of determination $\left(R^{2}\right)$ as a measure of the proportion of the phenotypic variation explained by the markers observed using Q-gene (27). Associations of markers with loci involved in resistance to the two rust diseases were evaluated by comparing the mean leaf rust and stripe rust severities for the two genotypic classes at each marker locus by a single factor analysis of variance.

When AFLP markers associated with resistance were identified in the 'Avocet $S$ ' $\times$ 'Pavon 76' population, these markers were tested on the selected $F_{3}$ lines from the 'Lalbahadur' $\times$ 'Lalbahadur (Pavon 1B)' cross as well as the parents of the ITMI population.

AFLP analysis. Forty-eight primer combinations of Pst I/MseI were used in AFLP analysis as described in Vos et al. (51) with some modifications (12). The restricted DNA (1 $\mu \mathrm{g})$ was ligated with double-stranded adaptors in the presence of T4-DNA ligase (Gibco BRL, Rockville, MD) in a volume of $60 \mu$ l. The sequence of the PstI adaptor was 5'-GAC TGC GTA GGT GCA-3'; 3'-GAG CAT CTG ACG CAT CC-5' and of the MseI adaptor was 5'-GAC GAT GAG TCC TGA G-3'; and 3'-TAC TCA GGA CTC AT-5'. Five microliters of the above ligation was amplified using preamplification primers in a polymerase chain reaction (PCR) reaction volume of $25 \mu \mathrm{l}$ containing $200 \mu \mathrm{M}$ dNTPs (Roche Diagnostics, Indianapolis, IN), $0.75 \mathrm{mM} \mathrm{MgCl}, 560 \mathrm{nM}$ each primer in $1 \times$ PCR buffer (Gibco BRL), and 2 units of Taq DNA polymerase (Gibco BRL). The PCR conditions included 25 cycles of $94^{\circ} \mathrm{C}$ for $30 \mathrm{~s}, 56^{\circ} \mathrm{C}$ for $1 \mathrm{~min}$, and $72^{\circ} \mathrm{C}$ for $1 \mathrm{~min}$. A sample of the digested DNA and preamplified DNA was checked on $1 \%$ agarose gel to determine the quality of the digestion and the preamplification. The preamplification primer for Pst I adaptor was 5'-GAC TGC GTA GGT GCA GA-3', whereas the primer for

TABLE 1. Distribution of $F_{6}$ lines in the 'Avocet $S$ ' $\times$ 'Pavon 76' cross for leaf rust and stripe rust response categories based on 2 years of field data

\begin{tabular}{lccccccc}
\hline & \multicolumn{3}{c}{$\begin{array}{c}\text { Number of } \mathrm{F}_{6} \text { lines } \\
\text { with response }\end{array}$} & & \multicolumn{3}{c}{$\chi^{2}$ value $^{\mathrm{a}}$} \\
\cline { 2 - 4 } \cline { 7 - 8 } Disease & HPTR $^{\mathrm{b}}$ & HPTS $^{\mathrm{c}}$ & Other & & 2 genes & 3 genes & 4 genes \\
\hline Leaf rust & 25 & 27 & 94 & & 4.19 & $20.29^{*}$ & $\ldots$ \\
Stripe rust & 8 & 12 & 126 & & $52.53^{*}$ & 4.78 & 3.75 \\
\hline
\end{tabular}

a Expected ratios for $\chi^{2}$ tests: 2 genes, 0.219 HPTR, 0.219 HPTS, 0.561 other; 3 genes, 0.103 HPTR, 0.103 HPTS, 0.794 other; 4 genes, 0.048 HPTR, 0.048 HPTS, 0.904 other. * indicates significant $\chi^{2}$ value at $P=0.01$.

${ }^{\mathrm{b}}$ Homozygous parental-type resistant.

${ }^{\mathrm{c}}$ Homozygous parental-type susceptible.
MseI adaptor was 5'-GAT GAG TCC TGA GTA AC-3'. The remainder of the preamplified DNA $(20 \mu \mathrm{l})$ was diluted with $75 \mu \mathrm{l}$ of distilled $\mathrm{H}_{2} \mathrm{O}$. Three microliters of the diluted preamplified DNA was used in the second PCR for selective amplification. The selective-amplification PCR was in a volume of $20 \mu \mathrm{l}$ consisting of $200 \mu \mathrm{M}$ dNTPs (Roche Diagnostics), $1.5 \mathrm{mM} \mathrm{MgCl} 2,250 \mathrm{nM}$ MseI-selective amplification primer, and $100 \mathrm{nM}$ digoxigeninlabeled PstI-selective amplification primer in $1 \times$ PCR buffer and 3 units of Taq DNA polymerase (Gibco BRL). The selective amplification primers had the same sequence as the preamplification primer, except with two additional nucleotides. The PstIselective amplification primers were end-labeled with digoxigenin (Operon Technologies, Alameda, CA). The PCR conditions for the selective amplifications included a touch down program with an initial $94^{\circ} \mathrm{C}$ for $1 \mathrm{~min}$ followed by a starting annealing temperature of $65^{\circ} \mathrm{C}$ that decreased by $1^{\circ} \mathrm{C}$ for 10 cycles with a $90-\mathrm{s}$ extension step after each cycle. This was followed by another 23 cycles of $94^{\circ} \mathrm{C}$ for $30 \mathrm{~s}, 56^{\circ} \mathrm{C}$ for $30 \mathrm{~s}$, and $72^{\circ} \mathrm{C}$ for $1 \mathrm{~min}$. The selective amplification products $(5 \mu \mathrm{l})$ were checked with $1 \%$ agarose for quality and separated on acrylamide gels under denaturing conditions in $1 \times$ TBE $(0.09 \mathrm{M}$ Tris-borate and $0.002 \mathrm{M}$ EDTA). The gels were transferred overnight onto Hybond nitrocellulose filters and were detected with chemiluminescent detection procedures according to the protocols of Hoisington et al. (12). Each polymorphic AFLP marker was identified by the primer combinations along with a band number.

\section{RESULTS AND DISCUSSION}

Characterization of 'Avocet $S$ ' $\times$ 'Pavon 76' populations for leaf and stripe rust. 'Pavon 76' displayed $10 \%$ leaf rust and 5 to $15 \%$ stripe rust severities, whereas 'Avocet S' showed leaf and stripe rust severities of 90 to $100 \%$ in all trials. Both stripe rust and leaf rust severities of the population displayed a continuous pattern of distribution between the severities of the two parents (Fig. 1). 'Pavon 76', 'Avocet $S$ ', and all $F_{5}$ or $F_{6}$ populations displayed infection types MS or $\mathrm{S}$ to leaf rust in all trials. However, stripe rust infection types for 'Pavon 76' and 'Avocet S' were 5 to 6 and 8 , respectively, based on a 0 -to- 9 scale. The $F_{6}$ population also showed variation in infection type classifications (data not shown). Classifying the $\mathrm{F}_{6}$ lines into three response categories based on severity (HPTR, HPTS, and other) revealed that a minimum of two and three additive genes conferred adult plant resistance to leaf rust and stripe rust, respectively, (Table 1). One slow rusting additive gene in 'Pavon 76' was designated $L r 46$ by Singh et al. (46). High correlation coefficients ranging between 0.86 and 0.89 among the rust severity data of the lines collected over 3 years is a strong indication of the reliability and consistency of the field data in our unreplicated trials (Table 2). Furthermore, high correlation coefficients of 0.71 to 0.85 between the

TABLE 2. Pearson correlation coefficients $(r)$ between leaf rust and stripe rust severity data for 3 years and adult-plant infection type to stripe rust (1 year) in 'Avocet $S$ ' $\times$ 'Pavon 76' population

\begin{tabular}{|c|c|c|c|c|c|c|}
\hline \multirow[b]{2}{*}{ Trait/year } & \multicolumn{3}{|c|}{ Stripe rust } & \multicolumn{3}{|c|}{ Leaf rust } \\
\hline & $1996^{\mathrm{a}}$ & $1997^{b}$ & $1999^{b}$ & $1996-97^{a}$ & $1997-98^{b}$ & $1999^{b}$ \\
\hline \multicolumn{7}{|l|}{ Stripe rust } \\
\hline 1997 & 0.86 & & $\ldots$ & $\ldots$ & $\ldots$ & $\ldots$ \\
\hline 1999 & 0.87 & 0.87 & $\begin{array}{l}\cdots \\
\ldots\end{array}$ & $\begin{array}{l}\cdots \\
\ldots\end{array}$ & $\begin{array}{l}\cdots \\
\ldots\end{array}$ & $\ldots$ \\
\hline \multicolumn{7}{|l|}{ Leaf rust } \\
\hline 1996-97 & 0.74 & 0.82 & 0.78 & $\ldots$ & $\ldots$ & $\ldots$ \\
\hline 1997-98 & 0.76 & 0.85 & 0.81 & 0.86 & $\ldots$ & $\ldots$ \\
\hline 1999 & 0.71 & 0.79 & 0.79 & 0.87 & 0.89 & $\ldots$ \\
\hline \multicolumn{7}{|l|}{ Stripe rust } \\
\hline Infection type & 0.66 & 0.66 & 0.73 & 0.58 & 0.56 & 0.58 \\
\hline
\end{tabular}

a Data on $\mathrm{F}_{5}$ lines.

${ }^{b}$ Data on $\mathrm{F}_{6}$ lines. 
leaf rust and stripe rust severity (Table 2) indicated that resistance genes to leaf rust were either closely linked or pleiotropic to genes that conferred resistance to stripe rust. The stripe rust infection type variation in the $\mathrm{F}_{6}$ population was also highly correlated to both leaf rust and stripe rust severity variation (Table 2), indicating that at least one of the genes that confers resistance to leaf rust and stripe rust also has an association with reduced adultplant infection type to stripe rust.

BSA of 'Avocet $S$ ' $\times$ 'Pavon 76' $\mathbf{F}_{6}$ lines. When $\mathrm{F}_{6}$ lines were chosen for BSA, both leaf rust and stripe rust severities were considered. The seven $\mathrm{F}_{6}$ lines chosen for inclusion in the resistant bulk had average stripe rust severities of 3 to $9 \%$, and leaf rust severities of 10 to $11 \%$ during the 2 years. In contrast, the 11 entries that were selected for inclusion in the susceptible bulk had average severities of 95 to $98 \%$ for stripe rust and 75 to $100 \%$ for leaf rust during the 2 years, respectively.

Of the 48 Pst I/MseI primer combinations tested, two primer combinations identified clear polymorphism between 'Avocet S', 'Pavon 76', and the resistant and susceptible bulks. These primer combinations were tested across the entire population. One primer combination provided an AFLP product, PstAAGMseCTA-1, which was present in 'Pavon 76' and the resistant bulk, and absent in 'Avocet S' and the susceptible bulk. This AFLP marker was screened across the entire population. One-way analysis of variance indicated that this AFLP fragment was associated with factors that condition resistance to both rusts by explaining on average approximately 49 and $31 \%$ of the phenotypic variation $\left(R^{2}\right)$ for leaf rust and stripe rust, respectively (Table 3). The second AFLP product, PstAAGMseCGA-1, was present in 'Avocet S' and the susceptible bulk but absent in 'Pavon 76' and the resistant bulk and therefore it was associated with the susceptibility allele. This AFLP marker was also screened across the entire population and explained on average approximately 45 and $25 \%$ of the $R^{2}$ for leaf rust and stripe rust, respectively (Table 3 ). The percentage of phenotypic variation in infection type to stripe rust explained by PstAAGMseCTA-1 and PstAAGMseCGA-1 was 13 and $12 \%$, respectively. Linkage analysis using MAPMAKER determined that the two marker loci were tightly linked to each other with $4.5 \%$ recombination (with a LOD score of 16.7 ).

Characterization of $F_{3}$ lines in 'Lalbahadur' $\times$ 'Lalb (Pavon 1B)' cross for resistance to leaf rust. Singh et al. (46) identified and located Lr46 in chromosome $1 \mathrm{~B}$ of wheat by developing single chromosome substitution lines using a monosomic series of

TABLE 3. Simple linear regression analysis for association between the two amplified fragment length polymorphism markers and leaf rust, stripe rust, and infection type data in $\mathrm{F}_{5} / \mathrm{F}_{6}$ families of 'Avocet' $\times$ 'Pavon 76'

\begin{tabular}{lrcc}
\hline Trait & & & \\
\hline PstAAGMseCTA-1 & & $\begin{array}{c}\text { Phenotypic } \\
\text { variance }\left(R^{2}\right)\end{array}$ \\
Yellow rust 1996 & & & \\
Yellow rust 1997 & 46.4 & 0.0 & 24.9 \\
Yellow rust 1999 & 88.9 & 0.0 & 38.8 \\
Mean & 58.3 & 0.0 & 29.6 \\
Leaf rust (1996-97) & 64.5 & 0.0 & 31.1 \\
Leaf rust (1997-98) & 119.7 & 0.0 & 46.1 \\
Leaf rust (1999) & 163.5 & 0.0 & 53.9 \\
Mean & 114.4 & 0.0 & 47.1 \\
Infection type (stripe rust) & 132.5 & 0.0 & 49.0 \\
PstAAGMseCGA-1 & 21.6 & 0.0 & 13.4 \\
Stripe rust 1996 & & & 19.4 \\
Stripe rust 1997 & 33.4 & 0.0 & 30.1 \\
Stripe rust 1999 & 59.9 & 0.0 & 24.4 \\
Mean & 44.4 & 0.0 & 24.6 \\
Leaf rust (1996-97) & 45.9 & 0.0 & 41.2 \\
Leaf rust (1997-98) & 97.2 & 0.0 & 48.9 \\
Leaf rust (1999) & 133.2 & 0.0 & 45.7 \\
Mean & 106.2 & 0.0 & 45.3 \\
Infection type (stripe rust) & 112.2 & 0.0 & 11.7 \\
\hline
\end{tabular}

'Lalbahadur'. Line Lalb (Pavon 1B) carrying gene Lr46 displayed 20 to $30 \%$ leaf rust severity, whereas 'Lalbahadur' showed 80 to $100 \%$ severity levels. Based on the 2 years of data on 184 lines in five families, 40 lines were considered homozygous resistant, 96 segregating, and 48 homozygous susceptible (Table 4). The observed distribution of the $F_{3}$ lines was in accordance to the $1: 2: 1$ ratio expected for segregation of the single resistance gene, Lr46.

AFLP analysis of 'Lalbahadur' $x$ 'Lalb (Pavon 1B)' $\mathbf{F}_{\mathbf{3}}$ lines. Forty homozygous resistant and 40 homozygous susceptible $F_{3}$ lines from the single chromosome recombinant line population were selected for marker analysis. The AFLP marker PstAAGMseCTA-1 with approximately $300 \mathrm{bp}$, found in 'Pavon 76', was present in 'Lalb (Pavon 1B)' substitution line but absent in 'Lalbahadur' (Fig. 2). This AFLP fragment was also present in all 40 homozygous resistant families but was absent in 32 of the 40 susceptible families. Since this population was segregating for the gene Lr46, the data obtained indicated that the AFLP marker PstAAgMseCTA-1 was associated with $L r 46$ with a recombination value of approximately $10 \%$. Because this AFLP marker was also associated with adult plant resistance to stripe rust in the 'Avocet S' $\times$ 'Pavon 76' population, it may be inferred that a gene that confers adult plant resistance to stripe rust is closely linked to Lr46. We designated the gene conferring resistance to stripe rust as Yr29. Since 'Lalbahadur' shows considerable resistance to stripe rust, the 'Lalbahadur' $\times$ 'Lalb (Pavon 1B)' population could not be characterized for stripe rust reaction.

Mapping of AFLP markers in ITMI population. Due to the lack of a full linkage map of 'Avocet S' $\times$ 'Pavon 76', we used the ITMI mapping population to map and establish the genomic location of the identified AFLP markers. The ITMI map is the result of a global effort to develop a publicly available linkage map in wheat. Currently, the linkage map has more than 800 markers. The genotypic and phenotypic data for a wide array of agronomic and other traits are available in the Graingenes database. This population has been widely used in the characterization and mapping of many traits $(28,47,50)$. The two AFLP markers identified in BSA were tested on the parents of the ITMI population and the marker PstAAGMseCTA-1 showed parental polymorphism. This AFLP marker showed the highest association with leaf rust and stripe rust in the 'Avocet S' $\times$ 'Pavon 76' population and was mapped in the ITMI population. Genotypic data from the above database was used together with the segregation data obtained from PstAAGMseCTA-1 and linkage mapping was done using MAPMAKER. The newly identified marker for Lr46/Yr29 was mapped at the distal end of the long arm of chromosome 1B (Fig. 3).

Gene Lr46 is the second slow rusting gene that has been characterized after Lr34 and should be present in several wheat cultivars derived from CIMMYT spring wheat germplasm. Our unpublished results indicate that $L r 46$ increases latent period and decreases infection frequency and uredinial size similar to the effects of $L r 34$ (6). The linkage between $L r 46 / Y r 29$ is also similar to the linkage between slow rusting genes $\operatorname{Lr} 34 / \operatorname{Yr} 18(21,43)$. This

TABLE 4. Distribution of $\mathrm{F}_{3}$ families in 'Lalbahadur' $\times$ 'Lalbahadur (Pavon $1 \mathrm{~B})$ ' for leaf rust response categories based on 2 years of field data

\begin{tabular}{lcccc}
\hline & \multicolumn{3}{c}{$\mathrm{F}_{3}$ families (No.) and response } & \\
\cline { 2 - 4 } Family & $\begin{array}{c}\text { Homozygous } \\
\text { resistant }\end{array}$ & Segregating & $\begin{array}{c}\text { Homozygous } \\
\text { susceptible }\end{array}$ & $\chi^{2 \mathrm{a}}$ \\
\hline 1 & 7 & 22 & 7 & 2.11 \\
2 & 6 & 22 & 10 & 1.80 \\
3 & 10 & 17 & 11 & 0.47 \\
4 & 11 & 17 & 10 & 0.47 \\
5 & 6 & 18 & 10 & 1.06 \\
Total & 40 & 96 & 48 & 1.04 \\
\hline
\end{tabular}

a A11 $\chi^{2}$ values for 1:2:1 ratio were nonsignificant at $P=0.05$. 
indicates that loci, or linked slow rusting gene complexes that confer resistance to more than one disease exist in wheat. These linked/pleiotropic genes should simplify breeding for durable resistance to both leaf and stripe rusts because durable resistance

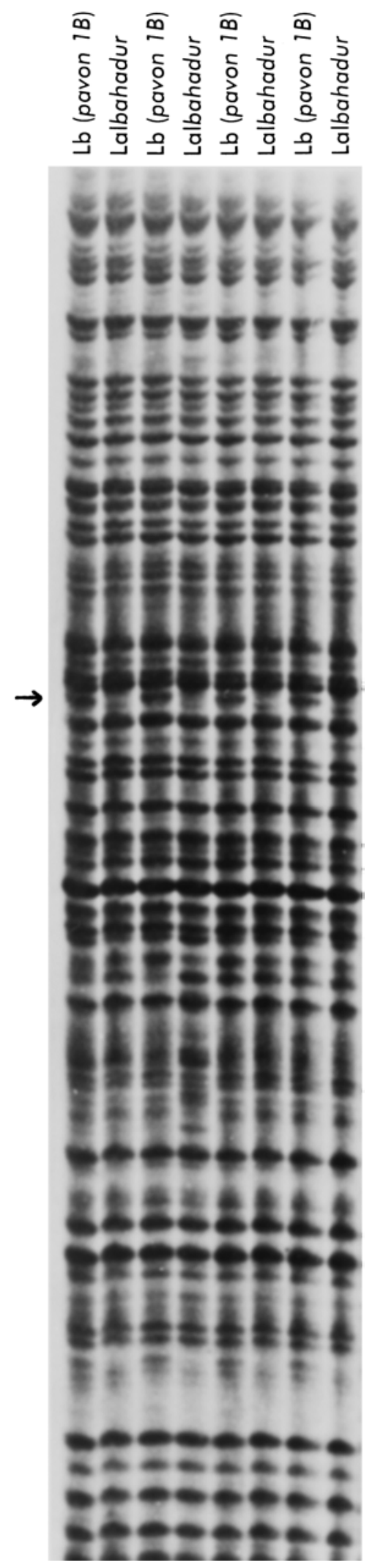

Fig. 2. Amplified fragment length polymorphism profile generated from genomic DNA of 'Lalbahadur' and 'Lalbahadur' with chromosome 1B substitution from 'Pavon 76' [Lb (Pavon 1B)] with PstAAGMseCTA-1. Different lanes containing 'Lalbahadur' and ' $\mathrm{Lb}$ (Pavon 1B)' are amplified from independent DNA extractions. The diagnostic band is indicated by an arrow. is often based on the interaction of only a few additive genes that have small to intermediate effects $(2,18,45,46,49,54)$.

We have demonstrated that bulked segregant analysis is an effective approach for developing molecular markers for genes that confer resistance to pathogens causing foliar diseases such as leaf rust and stripe rust and account for a significant proportion of the phenotypic variation. Developing full linkage maps in wheat is a challenging task due to the size of the wheat genome as well as the hexaploid nature of the species. Although traditional cytogenetic methods have been used effectively in assigning chromosomal locations for genes of interest, the power and the efficiency of the traditional approaches can be greatly enhanced by the use of molecular markers. We believe that for breeding programs such as CIMMYT, where one of the important breeding objectives is to incorporate durable and diverse resistance to rust diseases in wheat germplasm, characterization of additive genes and identification of a closely linked molecular marker will advance the selection process. Recent successes in cloning a race-specific rust resistance gene from cereals (5) or regions closely associated with such genes (11) have contributed to the understanding of the biochemical pathways associated with disease resistance. Fine mapping and cloning of closely linked/pleiotropic slow rusting genes such as $L r 46 / Y r 29$ or $L r 34 / Y r 18$ could help further our understanding of the functional aspects of durable disease resistance. To achieve this objective, we have initiated an effort to saturate the

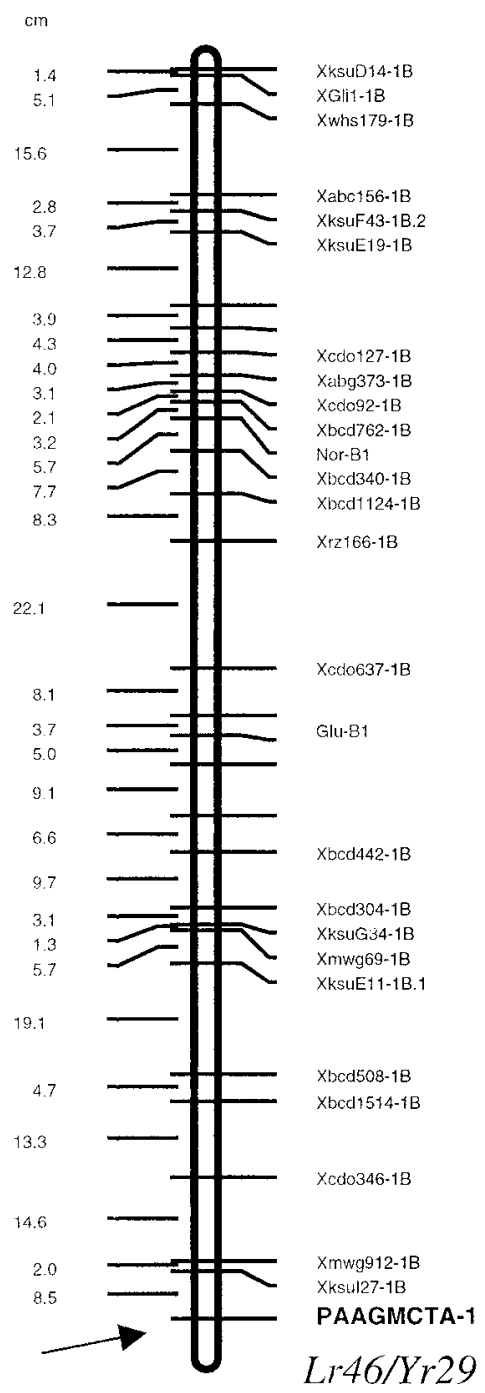

Fig. 3. Location of amplified fragment length polymorphism marker PstAAGMseCTA-1 and the likely location of $L r 46 / Y r 29$ (indicated by an arrow) in the ITMI linkage map for chromosome 1B. 
chromosome 1BL region, which carries $L r 46 / Y r 29$ with markers in order to further characterize this region and if possible identify flanking markers. In addition, since the genetic studies indicated the presence of a minimum of two to three other genes that confer resistance to leaf and stripe rust, work is also in progress to identify markers associated with these genes as well as to establish their genomic locations through BSA and partial linkage mapping.

\section{ACKNOWLEDGMENTS}

This study was supported by the Cooperative Research Center for Molecular Plant Breeding in Australia of which CIMMYT is a core partner. We thank C. J. Nelson for assisting in mapping involving the ITMI population and D. Poland for editorial review.

\section{LITERATURE CITED}

1. Anderson, J. A., Stack, R. W., Liu, S., Waldron, B. L., Fjeld, A. D., Coyne, C., Moreno-Sevilla, B., Mitchell Fetch, J., Song, Q. J., Cregan, P. B., and Frohberg, R. C. 2001. DNA markers for fusarium head blight resistance QTLs in two wheat populations. Theor. Appl. Genet. 102:1164-1168.

2. Bjarko, M. E., and Line, R. F. 1988. Heritability and number of genes controlling leaf rust resistance in four cultivars of wheat. Phytopathology 78:457-461.

3. Caldwell, R. M. 1968. Breeding for general and/or specific plant disease resistance. Pages 263-272 in: Proc. Int. Wheat Genetics Symp., 3rd. K. W. Finlay and K. W. Shephard, eds. Australian Academy of Sciences, Canberra, Australia.

4. Chague, V., Fahima, T., Dahan, A., Sun, G. L., Korol, A. B., Ronin, Y. I., Grama, A., Roder, M. S., and Nevo, E. 1999. Isolation of microsatellite and RAPD markers flanking the $\operatorname{Yr} 15$ gene of wheat using NILs and bulked segregant analysis. Genome 42:1050-1056.

5. Collins, N., Webb, C. A., Seah, S., Ellis, J. G., Hulbert, S. H., and Pryor, A. J. 1999. Molecular characterization of the maize $R p 1 D$ rust resistance haplotype and its mutants. Plant Cell 11:1-13.

6. Drijepondt, S. C., and Pretorius, Z. A. 1989. Greenhouse evaluation of adult-plant resistance conferred by the gene $\operatorname{Lr34}$ to leaf rust of wheat. Plant Dis. 73:669-671.

7. Dyck, P. L. 1977. Genetics of leaf rust reaction in three introductions of common wheat. Can. J. Genet. Cytol. 19:711-716.

8. Dyck, P. L., and Samborski, D. J. 1982. The inheritance of resistance to Puccinia recondita in a group of common wheat cultivars. Can. J. Genet. Cytol. 24:273-283.

9. Eastwood, R. F., Lagudah, E. S., and Appels, R. 1994. A directed search for DNA sequences tightly linked to cereal cyst nematode resistance genes in Triticum tauschii. Genome 37:311-319.

10. Feuillet, C., Messmer, M., Schachermayr, G., and Keller, B. 1995. Genetic and physical characterization of $\mathrm{Lrl}$ leaf rust resistance locus in wheat (Triticum aestivum L.). Mol. Gen. Genet. 248:533-562.

11. Feuillet, C., Schachermayr, G., and Keller, B. 1997. Molecular cloning of a new receptor-like kinase gene encoded at the $\mathrm{LrlO}$ disease resistance locus of wheat. Plant J. 11:45-52.

12. Hoisington, D., Khairallah, M., and Gonzalez-de-Leon, D. 1994. Laboratory protocols: CIMMYT Applied Molecular Genetics Laboratory. 2nd ed. International Maize and Wheat Improvement Center, Mexico, D.F.

13. Hsam, S. L. K., Huang, X. Q., and Zeller, F. J. 2001. Chromosomal location of genes for resistance to powdery mildew in common wheat (Triticum aestivum L. em. Thell.) 6. Alleles at the Pm5 locus. Theor. Appl. Genet. 102:127-133.

14. Johnson, R., and Law, C. N. 1975. Genetic control of durable resistance to stripe rust (Puccinia striiformis) in the wheat cultivar Hybride de Berse. Ann. Appl. Biol. 81:385-391.

15. Khan, A. A., Bergstrom, G. C., Nelson, J. C., and Sorrels, M. E. 2000. Identification of RFLP markers for resistance to wheat spindle streak mosaic bymovirus (WSSMV) disease. Genome 43:477-482.

16. Knott, D. R. 1989. The Wheat Rusts-Breeding for Resistance. SpringerVerlag, Berlin.

17. Kolmer, J. A. 1996. Genetics of resistance to wheat leaf rust. Annu. Rev. Phytopathol. 34:435-455.

18. Kuhn, R. C., Ohm, H. W., and Shaner, G. 1980. Inheritance of slow leaf rusting resistance in Suwon 85 wheat. Crop Sci. 20:655-659.

19. Lander, E. S., Green, P., Abrahamson, J., Barlow, A., Daly, M. J., Lincoln, S. E., and Newburg, L. 1987. MAPMAKER: An interactive computer package for constructing primary genetic linkage maps of experimental and natural populations. Genomics 1:174-181.
20. Marino, C. L., Nelson, J. C., Lu, Y. H., Sorrels, M. E., Lopes, C. R., and Hart, G. E. 1996. Molecular genetic maps of the group 6 chromosomes of hexaploid wheat (Triticum aestivum L. em Thell.). Genome 39:359-366.

21. McIntosh, R. A. 1992. Close genetic linkage of genes conferring adultplant resistance to leaf rust and stripe rust in wheat. Plant Pathol. 41:523527.

22. McIntosh, R. A., Hart, G. E., Devos, K. M., Gale, M. D., and Rogers, W. J. 1998. Catalogue of gene symbols for wheat. Pages 1-235 in: Proc. Int. Wheat Genet. Symp., 9th. Vol. 5. A. E. Slinkard, ed. Saskatoon, Canada.

23. McIntosh, R. A., Wellings, C. R., and Park, R. F. 1995. Wheat Rusts: An Atlas of Resistance Genes. CSIRO Publications, Melbourne, Australia.

24. McNeal, F. H., Konzak, C. F., Smith, E. P., Tate, W. S., and Russell, T. S. 1971. A uniform system for recording and processing cereal research data. U.S. Dep. Agric. Agric. Res. Ser. Bull. 34-121.

25. Messmer, M. M., Seyfarth, R., Keller, M., Schachermayr, G., Winzeler, M., Zanetti, S., Feuillet, C., and Keller, B. 2000. Genetic analysis of durable leaf rust resistance in winter wheat. Theor. Appl. Genet. 100:419-431.

26. Michelmore, R. W., Paran, I., and Kesseli, R. V. 1991. Identification of markers linked to disease-resistance genes by bulked segregant analysis: A rapid method to detect markers in specific genomic regions by using segregating populations. Proc. Natl. Acad. Sci. USA 88:9828-9832.

27. Nelson, J. C. 1997. Q-GENE: Software for marker-based genomic analysis and breeding. Mol. Breed. 3:231-245.

28. Nelson, J. C., Singh, R. P., Autrique, J. E., and Sorrells, M. E. 1997. Mapping genes conferring and suppressing leaf rust resistance in wheat. Crop Sci. 37:1928-1935.

29. Nelson, J. C., Van Deynze, A. E., Autrique, J. E., Sorrels, M. E., Lu, Y H., Merlino, M., Atkinson, M., and Leroy, P. 1995. Molecular mapping of wheat. Homoeologous group 2. Genome 38:517-524.

30. Nelson, J. C., Van Deynze, A. E., Autrique, J. E., Sorrels, M. E., Lu, Y. H., Negre, S., Barnard, M., and Leroy, P. 1995. Molecular mapping of wheat. Homoeologous group 3. Genome 38:525-533.

31. Parlevliet, J. E. 1975. Partial resistance of barley to leaf rust, Puccinia hordei. I. Effect of cultivar and development stage on latent period. Euphytica 24:21-27.

32. Peterson, R. F., Campbell, A. B., and Hannah, A. E. 1948. A diagrammatic scale of estimating rust severity on leaves and stems of cereals. Can. J. Res. Sec. C. 26:496-500.

33. Prins, R., Groenewald, J. E., Marais, G. F., and Snape, J. W. 2001. AFLP and STS tagging of Lr19, a gene conferring resistance to leaf rust in wheat. Theor. Appl. Genet. 103:618-624.

34. Rajaram, S., Singh, R. P., and Torres, E. 1988. Current CIMMYT approaches in breeding wheat for rust resistance. Pages 101-108 in: Breeding Strategies for Resistance to the Rust of Wheat. N. W. Simmonds and S. Rajaram, eds. International Maize and Wheat Improvement Center, Mexico, D.F.

35. Raupp, W. J., Singh, S., Brown-Guedira, G. L., and Gill, B. S. 2001. Cytogenetic and molecular mapping of the leaf rust gene Lr39 in wheat. Theor. Appl. Genet. 102:347-352.

36. Reiter, R. S., Williams, J. G. K., Feldmann, K. A., Rafalski, J. A., Tingey, S. V., and Scolnik, P. A. 1992. Global and local genome mapping in Arabidopsis thaliana by using recombinant inbred lines and random amplified polymorphic DNA. Proc. Natl. Acad. Sci. USA 89:1477-1481.

37. Roelfs, A. P. 1988. Resistance to leaf rust and stem rust in wheat. Pages 10-22 in: Breeding Strategies for Resistance to the Rusts of Wheat. N. W. Simmonds and S. Rajaram, eds. International Maize and Wheat Improvement Center, Mexico, D.F.

38. Roelfs, A. P., Singh, R. P., and Saari, E. E. 1992. Rust Diseases of Wheat: Concepts and Methods of Disease Management. International Maize and Wheat Improvement Center, Mexico, D.F.

39. Schachermayer, G., Messmer, M. M., Feuillet, C., Winzeler, H., Winzeler, M., and Keller, B. 1995. Identification of molecular markers linked to the Agropyron elongatum derived leaf rust resistance gene Lr24 in wheat. Theor. Appl. Genet. 90:982-990.

40. Schachermayer, G., Seidler, H., Gale, M. D., Winzeler, H., Winzeler, M., and Keller, B. 1994. Identification and localization of molecular markers linked to the $\operatorname{Lr} 9$ leaf rust resistance gene in wheat. Theor. Appl. Genet. 88:110-115

41. Seah, S., Bariana, H., Jahier, J., Sivasithamparam, K., and Lagudah, E. S. 2001. The introgressed segment carrying rust resistance genes $\operatorname{Yr} 17$, Lr37 and Sr38 in wheat can be assayed by a cloned disease resistance gene-like sequence. Theor. Appl. Genet. 102:600-605.

42. Singh, R. P. 1991. Pathogenicity variations of Puccinia recondita f. sp. tritici and $P$. graminis f. sp. tritici in wheat growing areas of Mexico during 1988 and 1989. Plant Dis. 75:790-794.

43. Singh, R. P. 1992. Genetic association of leaf rust resistance gene Lr34 with adult plant resistance to stripe rust in bread wheat. Phytopathology $82: 835-838$ 
44. Singh, R. P. 1993. Resistance to leaf rust in 26 Mexican wheat cultivars. Crop Sci. 33:633-637.

45. Singh, R. P., Huerta-Espino, J., and Rajaram, S. 2000. Achieving nearimmunity to leaf rust and stripe rust in wheat by combining slow rusting resistance genes. Acta Phytopathol. Entomol. Hungarica 35:133-139.

46. Singh, R. P., Mujeeb-Kazi, A., and Huerta-Espino, J. 1998. Lr46: A gene conferring slow-rusting resistance to leaf rust in wheat. Phytopathology 88:890-894.

47. Singh, R. P., Nelson, J. C., and Sorrels, M. E. 2000. Mapping Yr28 and other genes for resistance to stripe rust in wheat. Crop Sci. 40:11481155.

48. Singh, R. P., and Rajaram, S. 1992. Genetics of adult-plant resistance to leaf rust in 'Frontana' and three CIMMYT wheats. Genome 35:24-31.

49. Singh, R. P., and Rajaram, S. 1994. Genetics of adult plant resistance to stripe rust in ten spring bread wheats. Euphytica 72:1-7.

50. Van Deynze, A. E., Dubcovsky, J., Gill, K. S., Nelson, J. C., Sorrels, M. E., Dvorak, J., Gill, B. S., Lagudah, E. S., McCouch, S. R., and Appels,
R. 1995. Molecular genetic map for chromosome 1 in Triticeae species and their relation to chromosomes in rice and oats. Genome 38:47-59.

51. Vos, P., Hogers, R., Bleeker, M., Reijans, M., van de Lee, M., Hornes, A., Freijters, J., Pot, J., Peleman, M., Kuiper, M., and Zabeau, M. 1995. AFLP: A new technique for DNA fingerprinting. Nucleic Acids Res. 21:4407-4414.

52. William, H. M., Hoisington, D., Singh, R. P., and Gonzalez-de-Leon, D. 1997. Detection of quantitative trait loci associated with leaf rust resistance in bread wheat. Genome 40:253-260.

53. Williams, K., Taylor, S., Bogacki, P., Pallota, M., and Wallwork, H. 2001. Nematode resistance and tolerance genes located in wheat by bulked-segregant analysis combined with comparative mapping. Page 169 in: Plant and Animal Genome Conf., IX.

54. Zhang, Z. J., Yang, G. H., Li, G. H., Jin, S. L., and Yang, X. B. 2001. Transgressive segregation, heritability and number of genes controlling durable resistance to stripe rust in one Chinese and two Italian wheat cultivars. Phytopathology 91:680-685. 